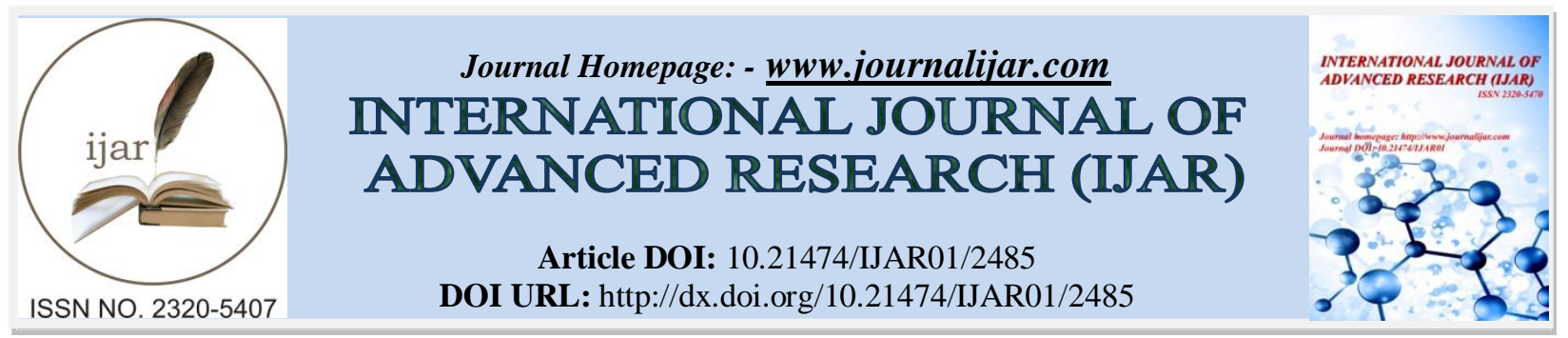

RESEARCH ARTICLE

\title{
A STUDY OF ROLES, RESPONSIBILITIES, PERFORMANCE AND STRENGTHENING MEASURES IN ROHTAK AND MEWAT DISTRICT PLANNING COMMITTEES.
}

Rajni Kumari.

Ex. Research Scholar, Department of Political Science, M.D. University, Rohtak.

\section{Manuscript Info}

Manuscript History

Received: 23 October 2016

Final Accepted: 21 November 2016

Published: December 2016

Key words:-

District planning committee, Grass-root, constitutional amendments, District planning.

\section{Abstract}

This paper study about the basic role the DPCs play at present, and shall perform in future in the formulation and implementation of integrated district development plans. It also study about the strengthening measures which would help the DPCs to perform their jobs to prepare the plans efficiently, effectively for social, economic, spatial development in Haryana with special reference to Rohtak and Mewat district.

\section{Introduction:-}

The foundation for bottom up planning approach laid by introducing $73^{\text {rd }}$ and 74 Constitutional Amendment Acts to the Indian Constitution in the year 1992-1993. The Government of Haryana amended the Haryana Panchayat Raj Act to incorporate the provisions of District Planning Committees (DPCs) as provided in the 73 and 74 Constitutional Amendment Acts (CAA). Provisions were made to establish DPCs in all the districts of the State as per section 310 of the Karnataka Panchayat Raj Act. The Government has issued a circular No. RDP ZPS 2000 dated 12-4-2001 describing the roles and responsibilities of DPCs.

Objectives:-

- To study the existing organizational structure and functioning of District Planning Committees,

- To analyze the positive and negative aspects of DPCs,

- To review the existing planning functions of DPCs,

- To assess the plans prepared and implemented with reference to objectives, and examine whether they are able to meet the desired goals.

- To suggest measures, and various capacity building requirements of DPCs including training of members, and to evolve policy and professional interventions for effective formulation and implementation of plans and projects by the DPCs.

\section{Methodology:-}

The study was carried out by selecting Rohtak and Mewat District Planning Committees.

Structured questionnaires were used to collect the data. 15 members and other officers of DPCs were randomly selected comprising Gram Panchayats, Municipalities, Taluk Panchayats and members of Zilla Panchayat from the two selected DPCs.

Secondary data was obtained from government circulars, proceedings of DPCs and the State Government. 


\section{Organisational Structure of DPC:-}

The composition of DPC consists of members of the house of the people and members of the council of states representing the district, chairperson of Zilla Panchayat and mayor or president of the district head quarter municipal body, together forming $20 \%$ of the size of the DPC, and the remaining $80 \%$ to be elected from among the members of the Zilla/Taluk/Gram Panchayats and Municipal Bodies in proportion of rural and urban areas of the district. The Zilla Panchayat president is the chairperson of the DPC and Mayor/President of the head quarter municipality is its vice-chairperson.

Functions of DPC:-

- To prepare 20 years perspective plan, mission and vision for the district based on the study of the existing problems and growth potential of both the rural and urban areas of the district.

- To prepare 5 Years development plans based on the above perspective plan

- To prepare annual plans.

- To prepare projects and schemes.

- To co-ordinate between the rural and urban local bodies on consensus building for the overall development of the district.

- To conduct expert studies in the direction.

DPC has a major role in preparing, scrutinizing and scanning of various plans of the rural and urban areas. Based on this exercise, any change and modification in the plans are incorporated by the concerned Zilla Panchayat, Taluk Panchayat, Gram Panchayat, City Municipal Council, Town Municipal Council or Pattana Panchayat.

As per the guidelines:

- The DPC has to conduct meetings regularly once in every three months.

- To implement the resolutions of the DPC, a separate sub committee is required to be formed under the supervision of the chief planning officer. This committee would work under the chief executive officer of the Zilla Panchayat.

The DPC has to identify common services that could be shared jointly among the rural and urban local bodies. For instance, extending urban water supply, sewerage system, and ring road facility to the nearby rural hinterland or facilitating the farmers to sell their agricultural produce in urban markets by providing market facilities and link roads. In reality, there could be many medium and long term infrastructure projects that need to be jointly prepared and budgeted by the rural and urban local bodies including the related government departments.

The DPC would from time to time evaluate the schemes and plans of the local bodies. These studies will be helpful to local bodies to correct their mistakes and to re-plan the projects/schemes. Based on the studies, the DPC could also prepare modified guidelines.

Financial Resources of DPCs:-

The funds are mainly available through annual contribution from the rural and urban local bodies, and they are given in Table - 1.

\begin{tabular}{|l|l|}
\hline Table - 1: Funds of District Planning Committee & Annual Contribution(Rs.) \\
Local Body & \\
\hline Gram Panchayat & $5000-00$ \\
Taluk Panchayat & $25,000-00$ \\
Zilla Panchayat & $2,00,000-00$ \\
Town Municipal Council/Panchayat & $7,500-00$ \\
City Municipal Council & $25,000-00$ \\
City Corporations & $1,00,000-00$ \\
\hline
\end{tabular}

The two types of finances for local bodies are internal and external resources. The internal resources are generated from taxation, fees, charges and penalties etc. The external resources are from Finance Commission/special grants, subsidies, government schemes, loans etc.

\section{Rohtak District Planning Committee:-}

As per the government notification No.RDP:ZPS:2000 dated 17/2/2000, the members of the Rohtak DPC were appointed as per the guidelines issued in 1996. As per the guidelines, four fifth of the members are from rural and urban local bodies in the district proportionate to the population. The Deputy Secretary of ZP was made the returning officer for conducting elections. 16 members were elected unopposed comprising 13 members from the rural local bodies and 3 members from the urban local bodies. In addition to the elected members, the members of legislative assembly and parliament of all the constituencies in the district, the members of the legislative council 
whose names are registered in the district voters list, the Deputy Commissioner of the district, and district in charge minister are permanent invitees to the DPC.

The chairperson and vice-chairperson of DPC are appointed by designation and the chairperson of the ZP is the chairperson of DPC and the president of district head quarter municipality i.e., Rohtak City Municipality is the vicechairperson of the DPC. In all, the DPC comprises of chairperson, vice-chairperson, 16 members elected from among the rural and urban local bodies, 3 MPs, 10 MLAs, 5 MLCs and the Deputy Commissioner of the district are the permanent invitees, and the chief executive officer of the ZP is the member secretary of the DPC. The Table - 2 illustrates the activities of Rohtak DPC since its inception.

Table - 2:- Activities of Rohtak DPC since Inception

\begin{tabular}{|c|c|c|}
\hline Sl. No. & Date & Important Decisions \\
\hline 1 & $5 / 7 / 2002$ & $\begin{array}{l}\text { To Prepare of taluk-wise Human } \\
\text { Development Indicators, } \\
\text { To organize workshop }\end{array}$ \\
\hline 2 & $7 / 3 / 2003$ & $\begin{array}{l}\text { The District Planning Cell is formed } \\
\text { within DPC comprising a team of } \\
\text { officers namely Chief Planning } \\
\text { Officer, Human Resource and } \\
\text { Project Officer, Asst. Statistical } \\
\text { Officer as members to monitor the } \\
\text { effective utilization of grants } \\
\text { released to local bodies. The Cell } \\
\text { has to submit a detailed report in the } \\
\text { next meeting. }\end{array}$ \\
\hline 3 & $16 / 7 / 2003$ & $\begin{array}{l}\text { Reviewed the GP-wise utilization of } \\
\text { grants. It was decided to prepare a } \\
\text { list of GP secretaries who are yet to } \\
\text { utilize more than } 10 \% \text { of the grants } \\
\text { released and a report to be } \\
\text { submitted. } \\
\text { Before preparing a long term plan, it } \\
\text { was decided to organize a workshop. }\end{array}$ \\
\hline 4 & $25 / 7 / 2003$ & $\begin{array}{l}\text { A workshop on bio-technology and } \\
\text { KRH }-2 \text { paddy breed was organized } \\
\text { in collaboration with department of } \\
\text { agriculture }\end{array}$ \\
\hline 5 & $12-3-2003$ & $\begin{array}{ll}\text { DPC organized a workshop on } & \text { on } \\
\text { district horticulture potential in } \\
\text { collaboration with department of } \\
\text { horticulture }\end{array}$ \\
\hline 6 & $15 / 9 / 2003$ & $\begin{array}{l}\text { A workshop on district development } \\
\text { perspective was organized }\end{array}$ \\
\hline 7 & 14-15 Nov., 2003 & $\begin{array}{l}\text { A state level Workshop on District } \\
\text { Perspective Plan was organized } \\
\text { through SATCOM at ANS SIRD } \\
\text { Mewat }\end{array}$ \\
\hline 8 & $16 / 10 / 2004$ & $\begin{array}{l}\text { A workshop on World Food Day } \\
\text { was organized }\end{array}$ \\
\hline 9 & $13 / 5 / 2005$ & $\begin{array}{l}\text { District Conference of } \\
\text { presidents, vice presidents } \\
\text { members of all GPs was held }\end{array}$ \\
\hline
\end{tabular}

It can be seen from the Table - 2 that the DPC has conducted three meetings during the period of 4 years and organized 6 workshops and conferences. Two DPC committee meetings convened on 17-2-2004 and 30-6-2004 
were adjourned due to non availability of quorum. When asked about the output of all the DPC meetings, the members explained about the lack of capacities, skills, professional expertise, administrative powers, and lack of coordination among the rural and urban local bodies and among various government organizations, and departments have had no clear out put in terms of perspective plan, medium term and annual plans in the district. So far only annual budgets of the local bodies are customarily placed before the DPC, which are just approved without making any modifications. This proves the ineffectiveness of DPC in the preparation and implementation of an overall integrated development plan for the district.

\section{Mewat District Planning Committee:-}

In Mewat DPC, there are a total number of 18 members from the local bodies including the chairperson and vice chairperson. 10 are elected unopposed from the rural local bodies and 6 are elected from among the elected members of the urban local bodies.

In addition, there are 17 permanent invitees who comprise of district in charge minister, two other ministers, one union minister, One MP of Mewat, eight MLAs, 3 MLCs and the DC of the district. CEO of the ZP is the member secretary.

The Mewat DPC has conducted four meetings since its inception. The first meeting was conducted on 27-2-2002 on the basic issues of constitution of DPC, powers of DPC and training of DPC members. The discussions with members and the officers of DPC have expressed that the DPC members were not aware of their duties and responsibilities. An important demand by the members was related to inadequate powers under the existing structure as they could not bring changes in the annual and medium term plans of the local bodies for effective output.

Members were apprehensive about the present functions and powers of DPC as provided by the government. As the local bodies at present have to prepare their own plans/annual budgets based on the needs, it is only a mere formality to place them before the DPC for approval. Municipalities normally send their annual budgets to the directorate of municipal administration/government even before they are placed before the DPC. Under such circumstances, the DPC members felt the need for review of the existing powers and functions of DPC.

In the second meeting held on 31-8-2002, the committee discussed on the ways and means of preparing district development/perspective plan for Mewat district. A decision was also taken to review the progress of plans prepared by the officers of different departments working in the district. The status of preparation of Taluk-wise/Assembly constituency-wise long term plans was reviewed. The committee expressed the need for constituting special committees for core subjects such as poverty alleviation, health and sanitation, education, social justice, administration etc.

\section{rd}

The 3 committee was conducted after a long gap of one and half years i.e. on 29-01-2004. Many district level officers were absent for the meeting. The committee took a decision to issue notice to the absentee officers.

Many members raised the question of powers and functions of the members and DPC. This point to the need for adequate training of the members of the DPC including the district level officers of different departments in the district.

In the fourth meeting held on 30-06-2004, the meeting approved the annual plans of the ZP and the ULBs. This meeting was attended by the district in charge minister, vice chairperson of state planning board, member secretary of the state planning board and members of DPC and other permanent invitees and district officers.

The committee approved the annual plan of the ZP and urban local bodies for the year 2004-05. The chairperson submitted a report to the district in charge minister and the vice Chairperson of the state planning board to solve the problems of the district at the government level. The report dealt with, (1) Releasing regular annual grant of Rs. 2.0 crore to DPC, (2) Separate grant to the service/area wise plans prepared by the respective committees and similar other issues related to the finance and services of $\mathrm{ZP}$.

The chairperson raised the issue related to provision of grants to urban areas/municipalities similar to the ZP. Some conflicting issues related to release of money for the projects such as drinking water supply, roads etc., directly to grama sabha were raised. The DPC members were in favor of channelising the funds through ZP to taluk and gram panchaayat. 


\section{Comparative Performance Assessment of Mewat and Rohtak DPCs}

The following Table - 3 illustrates the comparative performance of the Rohtak and Mewat DPCs in terms of 10 performance indicators. It is seen from the Table - 3 that both DPCs have performed very little in terms of the objectives set for the DPCs.

Table 3:- Performance Indicators of Rohtak and Mewat DPCs

\begin{tabular}{|c|c|c|c|}
\hline Sl. No. & Performance Indicators & Rohtak DPC & Mewat DPC \\
\hline 1 & $\begin{array}{l}\text { No. of meetings conducted } \\
\text { since the formation in } \\
2002 \text {. }\end{array}$ & 3 Meetings & 4 Meetings \\
\hline 2 & $\begin{array}{l}\text { Meetings postponed due to } \\
\text { non-quorum(Less than } \\
50 \% \text { attendance) }\end{array}$ & 2 Meetings & Nil \\
\hline 3 & $\begin{array}{l}\text { Whether 5 years plans } \\
\text { prepared as per the } \\
\text { government circular dated } \\
12 / 4 / 2001\end{array}$ & Not Yet & Not Yet \\
\hline 4 & $\begin{array}{l}\text { Whether the annual } \\
\text { contributions from the } \\
\text { rural and urban local } \\
\text { bodies received regularly }\end{array}$ & Partly & Partly \\
\hline 5 & $\begin{array}{l}\text { Annual budgets of ULBs } \\
\text { and rural local bodies } \\
\text { approved in DPC }\end{array}$ & Yes & Yes \\
\hline 6 & $\begin{array}{l}\text { Whether expert } \\
\text { committees formed with } \\
\text { all the departmental } \\
\text { officers as members and } \\
\text { elected members }\end{array}$ & Not yet formed. & $\begin{array}{l}\text { Following } 7 \text { committees } \\
\text { were formed; } \\
\text { 1.Agriculture and Related } \\
\text { Issues } \\
\text { 2. Poverty Alleviation } \\
\text { 3. Health \& Sanitation } \\
\text { 4. Education } \\
\text { 5. Social Justice } \\
\text { 6. Infrastructure } \\
\text { Services } \\
\text { 7. Administration }\end{array}$ \\
\hline 7 & $\begin{array}{l}\text { Whether these expert } \\
\text { committees were assigned } \\
\text { any job description }\end{array}$ & $\begin{array}{l}\text { Committees yet to be } \\
\text { formed }\end{array}$ & $\begin{array}{l}\text { To prepare plan for } 2005- \\
2020(15 \text { Years Perspective } \\
\text { Development Plan) }\end{array}$ \\
\hline 8 & $\begin{array}{l}\text { Do the expert committees } \\
\text { started working }\end{array}$ & Not yet & Not yet \\
\hline 9 & Training given to members & $\begin{array}{l}\text { - One day workshop } \\
\text { organized } \\
\text { - No Formal training on } \\
\text { the functions }\end{array}$ & - No formal training \\
\hline 10 & $\begin{array}{lcc}\text { Whether training } & \text { was } \\
\text { specific to } & \text { job } \\
\text { performance of DPC } & \end{array}$ & No & No \\
\hline 11 & $\begin{array}{l}\text { No. of studies conducted } \\
\text { to develop human } \\
\text { development indicators for } \\
\text { the district by the DPC }\end{array}$ & Not yet & Not yet \\
\hline
\end{tabular}

Mewat DPC has formed 7 committees as indicated in the Table - 3. Each committee is constituted with Officers of the concerned departments and headed by the elected member. Each committee is supposed to prepare medium and 
long term plan for the district in the related area. It is also noticed that the members of these committees are yet to start the work. In Rohtak, these committees have not yet been formed.

\section{Positive and Negative Aspects of Rohtak and Mewat DPCs:-}

\section{Positive Aspects:}

- DPC is headed by the chairperson of ZP, and the mayor/president of the district head quarter municipality is the vice-chairperson of DPC.

- MP/MLA/MLC including the district in charge minister is the permanent invitees of the DPC.

- The VIPs in the DPC could bring efficiency in the management of DPC.

- MPs/MLAs/MLCs as permanent invitee members could make available the respective grants given to them for the preparation and implementation of district development plan.

- Members are represented from both urban and rural local bodies.

- Could facilitate the grama sabhas and municipalities (ward sabhas are not yet set up in municipal areas).

- State government issued guidelines to prepare district development plan.

- Annual contributions by the local bodies.

- Could act as an overall coordinator for preparation and implementation of plans.

- Could act as a district planning unit.

- Could conduct studies and workshops at the district level covering the urban and rural problems.

- could prepare long term, medium term and annual plans and schemes both in the rural and urban areas keeping the overall development plan of the district.

- Could set up expert committees for rural and urban issues within DPC.

- State government can empower the DPC by amending the law so that all the departments in the district including the urban and rural local bodies jointly work with DPC while preparing and implementing the annual, medium and long term plans.

- A lump sum regular grant from SFC and Central Finance Commission could be released to DPC for preparation of plans.

Negative Aspects:-

- Lack of skills in social, economic and spatial planning among the members of the DPC.

- DPC at present failed to bring effective co-ordination among the urban and rural local bodies with regard to convergence of resources for projects having common interest.

- Integration is difficult as it seen as being against the interests of status quo

- Inadequate professional expertise in the DPC.

- Lack of technical professionals like planners, engineers, economists, social planners in the DPC.

- Absence of clear cut guidelines.

- Confusion among the elected members on the objectives of DPC.

- Dependent only on the existing employees already working in ZP.

- No powers are given to modify or change the existing plans or budget plans, schemes or projects. DPC can only provide suggestions for preparing and implementing the plans and schemes. The ultimate decision is left to the concerned local body.

- The power of the DPC is limited to the extent of providing technical and professional support in the preparation and implementation of plans.

- Do not have exclusive staff to deal with the preparation and monitoring of plans

- The departments and ULBs have their own rules and functions which at present may not allow them to work with DPC.

- At present, the government programmes/schemes are implemented by the respective departments/ULBs/rural local bodies.

- Convergence of resources (human and financial) for preparation and implementation of district development plan is difficult.

The members of DPC have expressed that the annual contributions by the local bodies are not regular. Many local bodies have not paid their annual contributions. At present, the fund mobilized with the Rohtak DPC as on 08-082005 is Rs. 1015677-00. The funds of DPC are at present utilized for organizing workshops, conferences and for conducting meetings. 


\section{Capacities of Mewat and Rohtak DPCs and Local Bodies:-}

The seven components were chosen to assess the capacity of the DPCs in performing their tasks. The Table - 4 illustrates the responses.

Table - 4:- Performance Assessment of DPCs in Rohtak and Mewat by the members of DPC (based on the responses of 15 members and the chief planning officers and other officers)

\begin{tabular}{|l|l|l|l|l|l|l|}
\hline SI No & $\begin{array}{l}\text { Components of } \\
\text { Capacity }\end{array}$ & $\begin{array}{l}\text { Exists to a } \\
\text { great extent }\end{array}$ & $\begin{array}{l}\text { Exists to } \\
\text { some extent }\end{array}$ & Do not Know & Not exists at all & Total \\
\hline 1 & $\begin{array}{l}\text { Clarity on vision and } \\
\text { perspective } \\
\text { development }\end{array}$ & $20 \%$ & $33 \%$ & $20 \%$ & $27 \%$ & 100 \\
\hline $\begin{array}{l}\text { Aware of roles and } \\
\text { responsibilities }\end{array}$ & $40 \%$ & $48 \%$ & $6 \%$ & $6 \%$ & 100 \\
\hline 3 & Have adequate powers & 0 & $20 \%$ & $27 \%$ & $53 \%$ & 100 \\
\hline 5 & Have adequate funds & 0 & $67 \%$ & $6 \%$ & $27 \%$ & 100 \\
\hline 6 & $\begin{array}{l}\text { Professional expertise } \\
\text { for planning }\end{array}$ & $\begin{array}{l}\text { Influence } \\
\text { mobilization } \\
\text { resources/funds of }\end{array}$ & $33 \%$ & $40 \%$ & $27 \%$ & 100 \\
\hline 7 & $\begin{array}{l}\text { Influence convergence } \\
\text { of resources }\end{array}$ & 0 & $20 \%$ & $26 \%$ & $46 \%$ & 100 \\
\hline
\end{tabular}

Table - 5:- Perception of Project/Plan Preparation Skills in Local Bodies(Urban and Rural).

\begin{tabular}{|l|l|l|l|}
\hline (Responses of 15 Officers) Response & Available & Available to some extent & Not at all \\
\hline Scheme/Project formulation staff & $18 \%$ & $45 \%$ & $27 \%$ \\
\hline $\begin{array}{l}\text { Sufficient engineering/ } \\
\text { professional experts }\end{array}$ & $9 \%$ & $30 \%$ & $61 \%$ \\
\hline Full-fledged Project team & 0 & $30 \%$ & $70 \%$ \\
\hline
\end{tabular}

Table - 6:- Status of Evaluation and Documentation of Projects/Schemes in Local Bodies (Responses of 15 persons comprising Municipal Commissioners.

\begin{tabular}{|l|l|l|l|l|}
\hline $\begin{array}{l}\text { Engineers and Elected representatives. } \\
\text { Response }\end{array}$ & Yes & To some extent & No & Do not know \\
\hline Is there a system to evaluate the projects & $15 \%$ & $15 \%$ & $15 \%$ & $55 \%$ \\
\hline $\begin{array}{l}\text { Is there a system to document the } \\
\text { success/failure experiences of projects }\end{array}$ & $18 \%$ & $36 \%$ & $21 \%$ & $25 \%$ \\
\hline $\begin{array}{l}\text { Any project evaluated after its } \\
\text { implementation }\end{array}$ & $15 \%$ & $15 \%$ & $15 \%$ & $55 \%$ \\
\hline $\begin{array}{l}\text { Any successful scheme documented after } \\
\text { implementation }\end{array}$ & $15 \%$ & $15 \%$ & $30 \%$ & $40 \%$ \\
\hline
\end{tabular}

From the responses given against the seven assessment criteria, a majority of the responses, $60-80 \%$ express that they either do not know or not having any awareness about major assessment criteria. An average of 30\% expresses those seven components of capacity criteria exist only to some extent. $40 \%$ of them are aware of their roles and responsibilities but other factors hindered xthe functioning. Table -5 illustrates the fact that the officers working in ULBs and rural local bodies have expressed on the lack of project preparation skills in these bodies, which reflects status of DPC also. Table - 6 above shows that only $15 \%$ of the respondents have expressed the availability of system/skills in local bodies for evaluating and documenting the schemes or projects after the implementation of projects.

Apart from the above funds, the state government may at its discretion provide financial assistance for effective functioning of the DPCs. But, so far the DPCs have not got any additional fund from the state or central government. 
When a question was posed to the members on why they need funds, many of them expressed that funds are necessary to prepare and implement the plan. To prepare the plan, they need to independently conduct studies, as at present the DPC is not equipped with experts and required personnel. Under the guidelines, expert committees for each core area such as poverty alleviation, health and sanitation, education etc., need to be constituted. The members of these committees will be drawn from the departmental officers, NGOs, elected members of the DPC. So far these committees are not constituted in Rohtak. Whereas these committees are formed in Mewat DPC, but not yet functional.

\section{Need for Practical Approach in DPCs Planning process:-}

Although the broad guidelines for preparing plans are given to DPC, members are yet to implement them. The above analysis clearly provides the status of DPC. There are definitely basic problems. We must understand the fact that the planning is not for planners, and planning is not just spatial planning or land use planning. It is sum total of physical, spatial, economic, financial, social and institutional planning. In the existing institutional set up, the integration of these planning components has become difficult for the DPC. The rural and urban local bodies including the government departments have resorted to routine annual budgetary plans which they find it easy. And these annual budgetary plans are placed before the DPC for customary approval.

\section{Conclusions and Policy Suggestions:-}

- Functioning of DPCs is satisfactory. The planning at present takes place in a disjointed approach in the urban and rural areas. For instance, the projects of water supply, roads, schools, or hospitals etc., are implemented by the respective municipalities or the grama sabhas.

- At present, not much co-ordination is visible. There is a need for co-ordination of mutual sharing of amenities. This could be done by the DPC at the time of preparation and implementation of new plans. The individual municipalities or the rural local bodies could request the DPC to co-ordinate the common issues that could effectively solve conflicts and enable them to share resources with mediation of DPC.

- The DPC is constituted with elected members and all of them need basic training. There is a need for orientation on planning and why and how the short term, medium term and long term plans are prepared and implemented?

- The objectives and role of the DPC and its members need to be made clear.

- The local bodies have to evolve strict measures to collect internal resources. The resources generated internally and externally should be enough to meet the local plan implementation. But at present, internal resources collected by them are not sufficient. External resources are not adequate and dependent on the state and central government or external agencies.

- The expert committee members drawn from the departments and NGOs including the elected members need basic training in the integrated action planning, medium term planning and long term planning.

- Training in planning for social, financial, spatial, physical, economic etc., need to be given to all the experts and elected members of DPC.

- In all the meetings that are conducted, the focus is only on the rural development and projects related to rural areas. Focus should be on the entire district development, which includes both urban and rural development.

- So far the feedback is that DPC is concentrating more on the matters of individual projects and schemes of rural development. Focus should be to prepare the medium and long term plans within which the annual plans are to be chalked out for both rural and urban areas.

- The expert sub committees have been formed in Mewat. But they are yet to prepare the plans. These sub committees are to be legalized and adequate legislative binding need to be placed over them in order to make them prepare and implement plans.

- The DPC need to be strengthened with adequate technical and managerial and financial support from the town planning, engineering, financial, economic and social and all other departments of the government.

- It is seen from the discussion that the ULBs and the rural local bodies are preparing their own annual plans without considering the medium and long term vision and overall integrated development, which are just placed before the DPC for customary approval. This needs to be reviewed in the context of the DPC's role.

- Each sub-committee should have experts such as planner, financial expert, economist, engineer, developmental expert, socialists, NGO representative, representatives from private firms and all the related departmental experts.

- The training should be tailor made in two phases, first phase training is on the planning process and preparatory work for the different plans, and the second phase training could be after a gap of 3 months on preparation of plans based on the data and preparatory work the members have carried out.

- Once the plan is prepared by the DPC, implementation plan is to be prepared. The long term plan is sum total of medium plans and short term action plans. 
- The focus should be on implementation and monitoring, and monitoring has to be constantly done to review and modify the implementation process to get the desired output.

- At present the representation of urban local bodies in DPC is negligible. There are only three to five members. It is essential to give equal thrust to urban areas as they could act as engines of rural development.

- The PURA (Provision of Urban Amenities in Rural Areas) concept and scheme needs to be fully integrated into the medium and long term plan of the district.

- All the central and state government schemes and projects meant for the rural and urban areas have to be scanned and brought under one roof so that these schemes are implemented in an integrated manner to achieve the long term objective of the district development plan.

- The district Officers is to be made responsible to implement the plan as per the time schedule of the plan implementation.

\section{References:-}

1. Nagesh Jha, Prakash Chand Mathur, “Decentralisation and Local Politics “, Sage Publication, New Delhi, pp.9, 1999.

2. Jos C Raphael, “Decentralised Planning in India“, Anmol Publication, New Delhi, pp. 62, 1999.

3. Mahi Pal, "Decentralisation Planning and Development in India", Anmol Publication, New Delhi, pp. 88, 2008.

4. Hooja, Rakesh, P.C. Mathur, “'District and Decentralised Planning”, Rawat Publication, Jaipur, 1991.

5. Jos C Raphael, “'Decentralised Planning in India”, Anmol Publication, New Delhi, 1999.

6. Surat Singh, “ Decentralised Governance in India: Myth or Reality”, Deep \& Deep Publication, New Delhi, , pp (xi), 2004.

7. S.S. Chahar, " Governance at Grassroots level in India“, Kanishka Publication, New delhi, 2005.

8. T.M. Joseph, "Local Governance in India: Ideas, Challenges \& Strategies", Concept Publication, New Delhi, 2007.

9. K.C. Suri,“'A Decentralisation Success Story?” Economic and Political Weekly; Vol - XL, No. 15, April 09, 2005.

10. S.S. Chahar, “ Panchayati Raj in Haryana: An Overview in S.S. Chahar(ed.); Governance at Grassroots level in India, Kanishka Publication, New delhi, pp. 1-24, 2005.

11. Status of District Planning Committee formation in India, Rajni Kumari, International Journal of Advanced Research(IJAR), pp 383-386, Vol. 4, Issue 9, September 2016.

12. Comparative Assessment about the role of District Planning Committee in Jhajjar and Mewat District, Rajni Kumari, Dr. Pawan Kumar Sharma, Hindu, pp 213-215, Vol. 1, No. 2, Feb. - April 2014.

13. Status of District Planning Committee in Rohtak district, Rajni Kumari, Drashta Research Journal, pp 477-479, Vol. 2, Issue 8, June-August 2013.

14. Role of Democratic decentralization towards responsiveness in India, Rajni Kumari, International Journal of Scientific \& Engineering Research(IJSER), pp. 1-7, Vol. 4, Issue 3, March-2013.

15. Conceptualisation to Institutionalisation Grass-root Planning in Haryana, Rajni Kumari, International Journal of Advancements in Research \& Technology(IJoART), pp. 1-8, Vol. 2, Issue 3, March-2013.

16. Fiscal Decentralisation in India, Rajni Kumari, International Journal of Literary Studies(IJLS),pp. 262-266, Vol. 2, Issue 4, 2012.

17. District Planning Committee in Haryana: Rohtak, Jhajjar, Mewat; Rajni Kumari, International Journal of Advanced Research(IJAR), In Press.

18. Impact of Fiscal Decentralization on Policy of Local Governments; Rajni Kumari, International Journal of Advanced Research(IJAR), In Press.

19. A Critical study about the Decentralization Process in India; Rajni Kumari, International Journal of Advanced Research(IJAR), In Press. 